\title{
BRAF NM_004333.4:C.1799T>G
}

National Cancer Institute

\section{Source}

National Cancer Institute. BRAFNM 004333.4:C.1799T>G. NCI Thesaurus. Code C98346.

A nucleotide substitution at position 1799 of the coding sequence of the BRAF gene

where thymine has been mutated to guanine. 